\title{
Evaluarea şi managementul limfadenopatiei la copil: Când suspectăm o malignitate?
}

\author{
Monica Dragomir \\ Universitatea de Medicină şi Farmacie „Carol Davila“, Bucureşti, România \\ Institutul Oncologic „Prof. Dr. Al. Trestioreanu“, Bucureşti, România
}

\begin{abstract}
REZUMAT
Ganglionii limfatici sunt structuri normale şi unele grupe ganglionare pot fi palpabile la un pacient sănatos. Prezenţa ganglionilor limfatici anormali (,limfadenopatie“) poate fi un indiciu pentru o boală sistemică gravă, iar diagnosticul diferenţial poate fi unul amplu. Provocarea pentru medicul de familie şi pediatru este de a distinge adenopatiile patologice de cele nepatologice şi de a dezvolta o abordare raţională a evaluării patologiei ganglionare. Din cauza asocierii cu afecţiunile oncologice, limfadenopatia poate fi o sursă majoră de anxietate pentru părinţi. Este esenţial să se recunoască momentul în care este justificată îndrumarea către oncologul pediatru. Deşi descoperirea limfadenopatiei ridică uneori temeri legate de o boală gravă, de cele mai multe ori, este urmarea unor cauze infecţioase benigne. Majoritatea pacienţilor pot fi diagnosticaţi pe baza anamnezei atente şi a examenului fizic. Adenopatia localizată impune căutarea unei leziuni cauzale de vecinătate, precum şi evaluarea altor grupe ganglionare pentru a exclude limfadenopatia generalizată. În general, ganglionii limfatici cu diametrul mai mare de $1 \mathrm{~cm}$ sunt consideraţi anormali. Adenopatiile supraclaviculare sunt cele mai sugestive pentru malignitate. O perioadă de observare de trei până la patru săptămâni este prudentă la pacienţii cu adenopatii localizate cu caractere clinice de benignitate. Adenopatia generalizată implică întotdeauna investigaţii clinice suplimentare. În cazurile în care este indicată biopsia ganglionară, se recomandă biopsia excizională a celui mai afectat ganglion, ceea ce va permite anatomopatologului să stabilească diagnosticul de certitudine.
\end{abstract}

Cuvinte cheie: limfadenopatie, cancer, copil

Evoluția normală a țesutului limfoid este de creştere până la pubertate şi, ulterior, atrofie progresivă în restul vieții. Ganglionii normali sunt palpabili în special la copii cu vârste între 4 şi 8 ani. Doar ganglionii submandibulari, axilari şi inghinali se pot palpa la persoanele sănătoase. Limfadenopatia este mai frecventă la copiii mici, al căror sistem imun naiv răspunde frecvent la infecții repetate

\section{DEFINITIE}

Limfadenopatia reprezintă creşterea în dimensiuni a ganglionilor limfatici. Un ganglion este considerat patologic la dimensiuni care depăşesc 10 $\mathrm{mm}$ diametru. Excepții sunt ganglionii epitrohleari (patologic peste $5 \mathrm{~mm}$ diametru) şi ganglionii inghinali (patologic peste $15 \mathrm{~mm}$ diametru). Cel mai frecvent, adenopatiile apar secundar infecțiilor, sunt autolimitate şi nu necesită tratament.

\section{RĂSPUNSUL IMUN MEDIAT DE GANGLIONI}

În corpul uman, sunt aproximativ 600 de ganglioni. Limfa trece prin cel puțin un ganglion înainte de a se întoarce în torentul circulator. Ganglionii aferenți conțin antigene, inclusiv microorganisme distruse parțial. Limfa conține microorganisme şi citokine din ariile inflamatorii şi infectate. Microorganismele pot fi fagocitate, procesate şi prezentate ca antigene. Limfocitele proliferează în ganglion. Celulele B se maturează în plasmă şi secretă anticorpi. Infecțiile şi stimularea antigenică determină limfadenopatia. Cauzele creşterii de volum a unui ganglion sunt: hiperplazia, infiltraţia limfocitară şi edemul tisular. Ganglionii au numeroşi centrii germinali cu proliferare celulară activă. Simptomatologia de limfadenită acută reflectă răspunsul la infecție. Celulele maligne pot ajunge în ganglion şi apoi în alte părți ale corpului. Anatomia drenaju- 
lui limfatic ajută la identificarea leziunii patologice cauzale.

\section{CLASIFICARE PATOGENICĂ}

Limfadenopatia poate fi cauzată de proliferarea celulelor intrinseci ale ganglionului (limfocite, plasmocite, monocite, histiocite) sau de infiltrarea cu celule extrinseci: neutrofile sau celule maligne.

- Adenopatia inflamatorie prin inflamație loco-regională este un răspuns localizat al limfocitelor şi macrofagelor secundar unei infecții virale sau bacteriene.

- Adenita este inflamația localizată infiltrativă prin infecția ganglionului.

- Adenopatia malignă este cauzată de proliferarea neoplazică malignă a limfocitelor şi macrofagelor (în leucemii, limfoame) sau de infiltrarea ganglionului cu celule maligne pe cale limfatică de la o tumoră primară (metastaza ganglionară).

Anamneza şi examenul clinic minuțios sunt extrem de importante în diagnosticul unei adenomegalii.

\section{ANAMNEZĂ}

Întrebări care ,îngustează“" spectrul diagnosticului diferenţial.

\section{Caracteristicile adenopatiei}

1.1. Debutul, durata de când a fost observată adenopatia

- Adenopatia instalată acut este cu mare probabilitate determinată de un proces infecțios.

- Adenopatia cu durată de peste 4 săptămâni este o adenopatie cronică determinată de o infecție cronică sau o malignitate.

- Adenopatia unilaterală sau bilaterală acută este cauzată de infecții streptococice sau stafilococice în $40-80 \%$ dintre cazuri.

- Adenopatiile subacute sau cronice sunt determinate cel mai frecvent de boala ghearelor de pisică, infecții cu mycobacterii, toxoplasmoză, EBV, CMV, colagenoze ş.a.

\subsection{Simptomatologia asociată poate sugera} etiologia adenopatiei

- Febra, durerile în gât, tusea sugerează o infecție respiratorie înaltă

- Febra, transpirațiile nocturne, scăderea ponderală sugerează o infecție TBC sau limfom

- Febra, fără o cauză aparentă, astenia, artralgia sunt sugestive pentru colagenoze

\section{Infecțiile recente. Există o infecție recentă} care să explice adenopatia?

Sugestive pentru o infecție recentă sunt: simptomatologia respiratorie, erupțiile, tulburările de tranzit intestinal, durerile osoase sau articulare, tulburările de vedere, cefaleea.

3. Leziuni sau traumatisme cutanate. Zgârieturile de pisică, înțepăturile sau muşcăturile de animale, plăgile deschise, abcesele dentare sunt semne care pot ajuta la stabilirea etiologiei.

4. Contacte infecțioase sau călătorii. A fost înțepat de insecte sau a avut vreo infecție cu ocazia unei călătorii? (căpuşă - boală Lyme, tularemie). A fost în contact cu persoane bolnave? A fost contact sau a avut infecții EBV/CMV sau TBC?

5. Statusul imunizărilor. Imunizarea $M M R$ (rujeolă - rubeolă - oreion) poate determina adenopatii inflamatorii.

6. Medicație. Medicamente care pot determina adenopatii: carbamazepină, fenitoină, cefalosporine, penicilină, pyrimetamină.

7. Alergiile pot fi cauză de adenopatii loco-regionale.

8. La adolescent, se vor pune întrebări legate de consumul de droguri şi contacte sexuale.

9. Pisici. Prezența pisicilor în anturajul copilului sugerează toxoplasmoză sau bartonelloză.

10. Alimente. Ingestia de lapte nepasteurizat poate fi legată de bruceloză. Consumul de carne insufucient preparată poate determina toxoplasmoză sau tularemie.

\section{EXAMENUL CLINIC}

Copiii au frecvent adenopatii palpabile, ca răspuns la infecții. Adenopatiile palpabile mai frecvent până la vârsta de 12 ani sunt ganglionii cervicali anteriori, inghinali, axilari. Ganglioni palpabili în regiunea cervicală, cu diametru mai mare de 1 $\mathrm{cm}$, sunt frecvent întâlniţi la copii, în procente de $38-45 \%$. În majoritatea cazurilor, reprezintă un răspuns tranzitoriu la infecții localizate sau generalizate. Adenopatiile palpabile în regiunea supraclaviculară sunt frecvent asociate cu malignități (tumori toracice sau abdominale) şi necesită trimitere imediată într-un centru oncologic.

Examenul fizic amănunțit este important în evaluarea febrei, a statusului ponderal (a pierdut în greutate recent?), a stării generale. Trebuie acordată atenție deosebită regiunii capului şi gâtului, abdomenului şi tegumentelor.

Examenul clinic al regiunii capului şi gâtului va căuta infecții ale scalpului (dermatită seboreică, ti- 
nea capitus), congestie conjunctivală. Se vor examina: orofaringele pentru faringite, probleme dentare, gingivostomatită herpetică, urechile pentru otită medie.

Examenul abdomenului va căuta hepatosplenomegalia şi tumori abdominale (ex. neuroblastom).

Examenul tegumentelor: se vor căuta erupții de orice fel, peteşii, purpură, echimoze (trombocitopenie!).

\section{EXAMENUL CLINIC AL ADENOPATIEI}

Palparea adenopatiilor trebuie să evalueze:

1. Dimensiunea adenopatiei. Nu este decisivă pentru diagnosticul de malignitate.

2. Localizarea. Adenopatiile cervicale şi axilare sugerează boala ghearelor de pisică, adenopatiile cervicale sugerează mononucleoză, adenopatiile inghinale pot apărea legat de boli cu transmitere sexuală. Adenopatiile generalizate se întâlnesc în boli de sistem.

3. Blocurile adenopatice reprezintă un grup de ganglioni care par conectați şi se mobilizează împreună. Sunt caracteristice pentru sarcoidoză, TBC, metastaze limfatice de la o tumoră solidă, limfom malign.

4. Consistența. Consistența fermă, dură este sugestivă pentru metastază carcinomatoasă, consistența ferm-elastică este caracteristică pentru limfom malign, consistența scăzută caracterizează adenopatiile infecțioase şi inflamatorii. Consistența fluctuentă sugerează adenită supurativă. Adenopatiile cu consistență de ,alice“sub piele caracterizează infecțiile virale.

5. Sensibilitatea. $\mathrm{Nu}$ face întotdeauna diferența între benign/malign. Durerea poate fi consecința creşterii rapide în dimensiuni a ganglionului şi distensia capsulei, a inflamaţiei sau supurației, dar şi a hemoragiilor în centrul necrotic al unui ganglion malign.

\section{Riscul de malignitate a unei adenopatii}

- Risc scăzut de malignitate: diametru mai mic de 1-2 cm, localizare cervicală, inghinală sau axilară, eritem asociat, sensibilitate dureroasă, căldură locală, fluctuență.

- Risc crescut de malignitate: localizare occipitală, auriculară, supraclaviculară, mediastinală, epitrohleară, cervicală posterioară, consistență fermă, lipsa durerii, diametru mai mare de $2 \mathrm{~cm}$, asociere cu simptomatologie sistemică.

\section{DIAGNOSTIC DIFERENŢIAL}

1. ADENOPATIE GENERALIZATĂ: mai mult de 2 grupe ganglionare non-contigue

Cauze infecțioase:

- Infecții virale: IACRS, varicelă, rujeolă, rubeolă, hepatită, HIV, EBV, CMV, adenovirus

- Infecții bacteriene: sifilis, bruceloză, TBC, sepsis

- Micoze: histoplasmoză, coccidioidoză

- Toxoplasmoză

Boli inflamatorii neinfecțioase: sarcoidoză, artrită reumatoidă, lupus, boli de stocaj (Niemann Pick, Gaucher)

Malignități: leucemii, limfoame, neuroblastom

Reacții medicamentoase: fenitoină, allopurinol Hipertiroidism

2. ADENOPATIE LOCALIZATĂ: un grup ganglionar sau adenopatii contigue

Regiunea capului şi gâtului

Cauze infecțioase: Infecții respiratorii virale, mononucleoză, faringite streptococice grup A, limfadenite bacteriene acute, boală Kawasaki, rubeolă, boala ghearelor de pisică, toxoplasmoză, TBC şi infecții cu mycobacterii atipice

Cauze maligne: $25 \%$ dintre malignitățile copilului apar în regiunea capului şi gâtului

- Copii mai mici de 6 ani: leucemii, limfoame, neuroblastom, rabdomiosarcom

- Copii mai mari de 6 ani: limfoame Hodgkin şi non-Hodgkin

Regiunea mediastinală: adenopatiile nu se palpează direct. Evaluarea se face indirect prin prezența ganglionilor supraclaviculari. Adenopatiile mediastinale pot fi însoțite de tuse, disfagie, hemoptizie în cadrul unui sindrom de venă cavă superioară (urgență medicală!).

Etiologie: leucemie acută, limfom malign, sarcoidoză, fibroză chistică, TBC, histoplasmoză.

Regiunea supraclaviculară (asociat cu boli grave!): limfom, TBC, histoplasmoză.

Regiunea axilară: infecții locale, boala ghearelor de pisică, ARJ, hidrosadenită supurativă, limfoame non-Hodgkin.

Abdomen: adenopatiile se pot manifesta ca durere abdominală, durere lombară, micțiuni frecvențe, constipație, obstrucție intestinală prin invaginație. Pot apare în limfadenită mezenterică sau în limfomul malign.

Inghinal: infecții locale, dermatită de scutec.

Este foarte important să excludem o malignitate. În absența oricăror semne şi /sau simptome sugestive pentru un proces malign, adenopatia 
trebuie monitorizată atent până la dispariție. Dacă adenopatia nu se remite în 4 săptămâni, este considerată cronică şi doar biopsia ganglionară poate exclude o malignitate.

INDICATIILE BIOPSIEI GANGLIONARE sunt:

- Creşterea în dimensiuni a adenopatiei după 2-3 săptămâni de tratament antibiotic

- Ganglioni care nu au crescut în dimensiuni, dar nici nu au scăzut în dimensiuni în 6-8 săptămâni

- Adenopatii asociate cu orice anomalie de mediastin la radiografia de torace

- Adenopatie asociată cu scădere ponderală, hepatosplenomegalie, febră fără cauză evidentă şi/sau transpirații nocturne

- Adenopatii localizate auricular posterior, epitrohlear sau supraclavicular

\section{ADENOPATIILE ÎN PATOLOGIA MALIGNĂ LA COPIL}

Leucemii acute: Adenopatiile sunt prezente la debut în 50\% dintre cazuri; sunt de obicei mari şi cresc rapid în dimensiuni. Alte manifestări clinice asociate: paloare, febră, peteşii, dureri generalizate, echimoze, hepatosplenomegalie. Hemogramă modificată: pancitopenie, numărul de leucocite poate fi normal sau crescut. Debut posibil cu o afecțiune acută intercurentă care nu evoluează favorabil la tratament antibiotic.

Limfom Hodgkin: Rar la copii sub 4 ani. Aspect clinic al adenopatiei: „ca nucile în sac“. Ganglioni nedureroşi, fermi, mobili, uneori cu fenomene inflamatorii. Simptomatologie sistemică asociată în 30\% dintre cazuri: febră, anorexie, scădere ponderală, prurit.

Limfom non-Hodgkin. Debut mai brusc, aparent în plină sănătate. Poate apărea la copii mici,

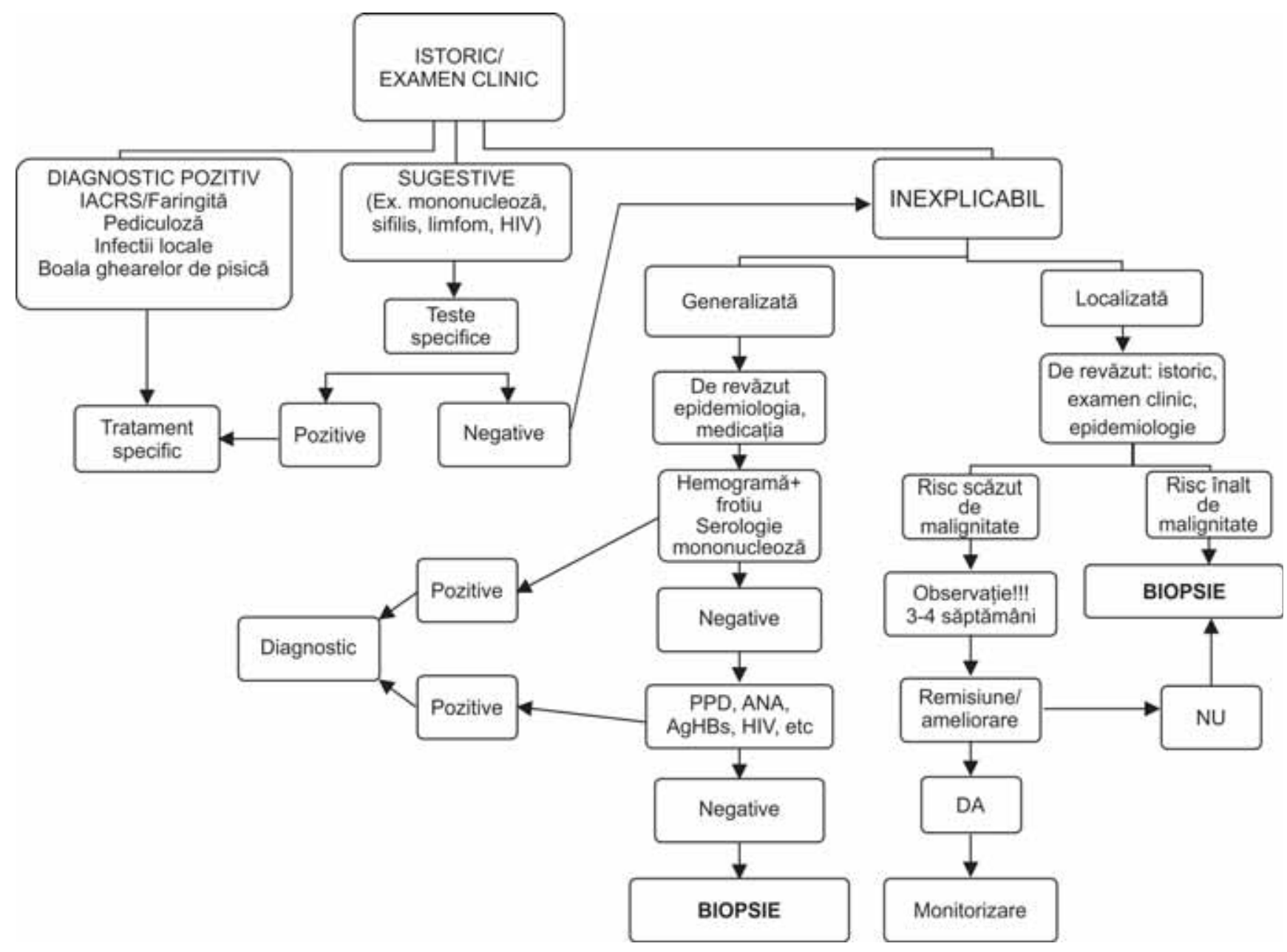

FIGURA 1. Algoritm de evaluare a unui pacient cu limfadenopatie 
sugari (limfoame abdominale). Mai frecvent la copii cu vârste mai mici de 10 ani. De multe ori, stadiul bolii la diagnostic este avansat. Localizări la debut: abdomen $45 \%$; mediastin $25 \%$; cap şi gât 10-20\%; ganglioni superficiali 5-10\%; alte localizări $5-10 \%$.

Neuroblastom cu debut în lanțurile ganglionare ale sistemului nervos simpatic. În regiunea cervicală determină sindrom Horner (mioză , ptoză palpebrală, enoftalmie).

Alte malignități: metastaze ganglionare de la rabdomiosarcoam, carcinom de rinofaringe, carcinom tiroidian.

\section{ALGORITM DE EVALUARE A UNUI PACIENT CU LIMFADENOPATIE}

Care este atitudinea corectă în fața unei adenopatii descoperite la un copil cu ocazia examenului clinic, indiferent de cauza pentru care familia a solicitat consultul medical?

În urma anamnezei şi examenului clinic atent, ne aflăm în fața a 3 situații (Fig. 1):

1. Diagnosticul afecțiunii care a determinat o adenopatie cu caractere clinice de benignitate este stabilit: infecție respiratorie acută, pediculoză, infecție locală, boala ghearelor de pisică etc. Se inițiază tratamentul corespunzător. Se monitorizează pacientul până la vindecarea bolii şi remisiunea adenopatiei.

2. Diagnosticul sugerat de examenul clinic şi anamneză este de infecție specifică: mononucleoză, HIV, sifilis. Se efectuează testele serologice şi, în cazul în care diagnosticul este confirmat, se instituie tratamentul etiologic. Se urmăreşte pacientul până la vindecare şi remisiunea adenopatiei. În ca- zurile în care testele specifice sunt negative, ne aflăm în fața unei ,adenopatii fără cauză stabilită“"

3. Adenopatii fără cauza stabilită prin investigațiile de primă intenție. În această situație, sunt reluatw anamneza, medicația primită de pacient şi examenul clinic minuțios, se reevaluează contextul epidemiologic.

Există două situații posibile:

3.1. Adenopatie generalizată. Se efectuează hemogramă completă cu frotiu şi test de mononucleoză. Testul pozitiv va confirma diagnosticul şi se va institui tratamentul antibiotic. În cazul în care testul este negativ, se vor efectua alte teste serologice care ar putea preciza contextul patologic în care au apărut adenopatiile: anticorpi antinucleari, intradermoreacţie la PPD, test HIV, Ag. HBS ş.a. În cazul în care testele pozitive stabilesc diagnosticul, se inițiază tratamentul corespunzător. În cazul în care testele efectuate sunt negative, se recomandă biopsia ganglionară.

3.2. Adenopatie localizată

- Dacă adenopatia se încadrează în categoria de „risc scăzut de malignitate“ (pe baza criteriilor menționate anterior), pacientul rămâne în observație 3-4 săptămâni. Dacă, în acest interval de timp, se observă remisiunea parțială sau completă a adenopatiei, menținem în observație copilul fără a lua altă atitudine terapeutică sau a efectua alte investigații. Dacă, în interval de 3-4 săptămâni, adenopatia se menţine sau creşte, se recomandă biopsia ganglionară.

- Dacă adenopatia se încadrează în categoria de „risc crescut de malignitate“, se recomandă biopsia ganglionară fără alte investigații care ar putea întârzia stabilirea diagnosticului de certitudine.

Conflict of interest: none declared Financial support: none declared 